\title{
An Experience of Telemedicine During COVID-19 Pandemic: Follow-up of Patients with Obesity Via Phone Interviews
}

\author{
COVID-19 Pandemisi Sırasında Bir Teletıp Deneyimi: Obezitesi Olan \\ Hastaların Telefon Görüşmeleriyle Takibi
}

\section{(D) Feray Akbaş, (D) Hanife Usta Atmaca, (D) Mehmet Emin Pişkinpaşa}

University of Health Sciences Turkey, İstanbul Training and Research Hospital, Clinic of Internal Medicine, İstanbul, Turkey

\section{Abstract}

Objective: Telemedicine means to provide healthcare services to remote patients using modern information technology like audio/video communications, computer and telemetry. During global Coronavirus diseases-2019 (COVID-19) pandemic, home isolation was advised for general population, especially for individuals who were at higher risk for infection, like people living with obesity. Here, it was aimed to evaluate the data obtained with a telemedicine method performed for obesity center patients' follow-ups during COVID-19 pandemic lockdown period and highlight the need for alternative follow-up methods for chronic diseases like obesity during crisis times.

Method: All registered obesity center patients were included in the study. Phone calls were made by the directing doctor and patients were asked about their diet compliance, exercise level, the way they felt, present weight, any problems about their accompanying diseases or obtaining their medications. Recommendations were made (healthy nutrition, hydration, home exercises, coping with distress, the necessity of home isolation, precautions needed to be taken when they have to go out). The answers were categorized and number of patients for each category were determined.

Results: The number of patients that were called was 101, 86 for those who answered and 15 for those who did not respond. When their last registered weight in $\mathrm{kg}$ was compared with the present weight declared by the patient, $40.7 \%$ had weight gain $(n=35), 50 \%$ had weight loss $(n=43)$ and $9.3 \%(n=8)$ patients had same weight. When they were asked about their food consumption, $27.9 \%(n=24)$ of patients were following the recommended diet, $29 \%(n=29)$ were not following any recommendations about their diet and $33 \%(n=33)$ were partially

\section{Öz}

\begin{abstract}
Amaç: Teletıp odyo/video iletişimi, bilgisayar ve telemetri gibi modern bilişim teknolojisini kullanarak uzaktaki hastalara sağlık hizmeti verilmesidir. Global Koronavirüs hastalığı-2019 (COVID-19) pandemisi süresince, genel popülasyona; özellikle obezitesi olan bireyler gibi yüksek enfeksiyon riski olan kişilere ev izolasyonu önerilmiştir. Burda, COVID-19 pandemisi izolasyon döneminde obezite merkezi hastalarının takibi için kullanılan teletıp yöntemi verilerinin değerlendirilmesi ve kriz zamanlarında obezite gibi kronik hastalıklar için alternatif takip metodlarının gerekliliğine dikkat çekilmesi amaçlanmıştır.
\end{abstract}

Yöntem: Obezite merkezinde kayıtlı tüm hastalar çalışmaya dahil edildi. Merkez yönetici hekimi tarafından telefon aramaları yapıldı ve hastalara diyet uyumları, egzersiz düzeyleri, nasıl hissettikleri, mevcut kiloları, eşlik eden hastalıkları ya da ilaçlarını temin etmede zorluk yaşayıp yaşamadıkları soruldu. Tavsiyelerde bulunuldu (sağlıklı beslenme, sıvı alımı, ev egzersizleri, stresle baş etme, ev izolasyonu zorunluluğu, dışarda olmak zorunluysa alınması gereken önlemler). Yanıtlar sınıflandırıldı ve her kategori için hasta sayısı belirlendi.

Bulgular: Toplam 101 hasta arandı, 86 hasta yanıt verdi ve 15 hasta yanıt vermedi. Son kayıtlı kilolarıyla karşılaştıııldığında \%40,7 $(n=35)$ hasta kilo almıştı, \%50 ( $n=43)$ hasta kilo vermişti ve \%9,3 $(n=8)$ hasta kilosunu korumuştu. Hastaların \% 27,9'u ( $n=24)$ tavsiye edilen diyete uyuyordu, $\% 29^{\prime} u(n=29)$ diyet konusunda hiçbir tavsiyeye uymuyordu ve \%33'ü $(n=33)$ diyet önerilerine kısmen uyuyordu. En sık yapılan yanlış tüm gün ve gece boyunca atıştırmaktı. Hastaların \%30,2'si $(n=26)$ düzenli olarak ev egzersizi yapıyordu, \%50 ( $n=43)$ hiç egzersiz yapmıyordu ve \%19,8 $(n=17)$ kısmen ev egzersizleri yapıyordu. En sık yapılan egzersiz evde-yürüme programlarıydı. Kendilerini nasıl hissettikleri sorulduğunda \%53,5 ( $n=46)$

Address for Correspondence: Feray Akbaş, University of Health Sciences Turkey, İstanbul Training and Research Hospital, Clinic of Internal Medicine, İstanbul, Turkey

E-mail: atlibatur@yahoo.com ORCID: orcid.org/0000-0001-5091-9160 Received: 31.08.2020 Accepted: 21.10.2020

Cite this article as: Akbaş F, Usta Atmaca H, Pişkinpaşa ME. An Experience of Telemedicine During COVID-19 Pandemic: Follow-up of Patients with Obesity Via Phone Interviews. Bagcilar Med Bull 2020;5(4):199-203

${ }^{\circ}$ Copyright 2020 by the Health Sciences University Turkey, Bagcilar Training and Research Hospital Bagcilar Medical Bulletin published by Galenos Publishing House. 


\section{Abstract}

following their dietary recommendations. The most common mistake was snacking throughout the day and at nighttime. When they were asked about their physical activity level, $30.2 \%(n=26)$ of patients were doing home exercises regularly, $50 \%(n=43)$ were not exercising at all and 19.8 $\%(n=17)$ were partially doing home exercises. The most common home exercise was home-walking programmes. When they were asked how they felt, $53.5 \%(n=46)$ of patients declared to be generally good, $24.4 \%$ $(n=21)$ were generally bad and $22.1(n=19)$ were partially good. The most common complaint was sleep disturbances and anxiety.

Conclusion: Telemedicine is an easy, safe and effective follow-up method for chronic diseases like obesity at extraordinary times like the pandemic period we are going through. Its application can be broader after medical and legal regulations become clear to let both the patients and the healthcare professionals who use this method be safe in all aspects.

Keywords: COVID-19 pandemic, obesity, telemedicine

\section{Öz}

hasta genel olarak iyi, \%24,4 ( $n=21)$ hasta genel olarak kötü, \%22,1 $(n=19)$ hasta kısmen iyi olduklarını belirtti. En sık şikayet uyku bozuklukları ve anksiyeteydi.

Sonuç: Teletıp, içinde bulunduğumuz pandemi periyodu gibi olağanüstü zamanlarda, obezite gibi kronik hastalıklar için kolay, güvenli ve etkin bir takip metodudur. Bu yöntemin uygulama alanı, kullanan hastalar ve sağık profesyonelleri için her anlamda güvenli olmasını sağlayacak medikal ve legal düzenlemeler yapıldıktan sonra genişleyebilecektir.

Anahtar kelimeler: COVID-19 pandemisi, obezite, teletıp

\section{Introduction}

Telemedicine means to provide healthcare services to remote patients using modern information technology like audio/video communications, computer and telemetry. It is a convenient method as it can provide health-care services across geographic, time, social and cultural barriers. World Health Organization makes a distinction between telemedicine and telehealth, emphasizing that telehealth is performed generally for preventive medicine purposes and telemedicine is performed for treatment purposes (1).

Starting late 2019 and early 2020, 2019 novel Coronavirus diseases-2019 (COVID-19) caused a global pandemic and has affected our country since March 2020, too. Turkish Ministry of Health declared the general precautions needed to be taken for the pandemic by healthcare facilities immediately. Our obesity center therapeutic education programme and obesity outpatient clinic were temporarily discontinued according to these precautions $(2,3)$.

Home isolation was advised for general population, especially for individuals who had high infection risk, like the elderly, immunosuppressed ones, or those with chronic illnesses. Obesity was among those chronic illnesses and people living with obesity were advised to stay at home strictly $(2,3)$.

Home isolation had some consequences like overeating, inactivity, increased stress levels, sleep disturbances which could easily lead to weight gain. Several studies from different countries highlighted this problem even for people with normal weight and the risk was bigger for individuals living with obesity. Thus, we decided to use telemedicine methods to follow up our patients (4-6).

Here, it was aimed to evaluate the data obtained with a telemedicine method performed for obesity center patients' follow-ups during COVID-19 pandemic and highlight the need for alternative follow-up methods for chronic diseases like obesity during crisis times.

\section{Material and Methods}

All registered obesity center patients were included in the study (98 female, 3 male, totally 101 patients). First, phone messages were sent informing the patients that they were going to be called by their doctor for follow-up. Then, the phone calls were made by the directing doctor. Patients were asked about their diet compliance, exercise level, how they felt, present weight, any problems about their accompanying diseases or obtaining their medications. Their questions were answered. Recommendations that needed to be followed at home during pandemic period for obesity and also for protection from COVID-19 were made (healthy nutrition, hydration, home exercises, coping with distress, the necessity of home isolation, precautions needed to be taken when being outside was a must). The answers were categorized and numbers of patients for each category were determined.

Study was conducted according to the Helsinki 2000 declaration. Verbal consent was obtained from all patients after all procedures had been fully explained. Ethical approval was obtained from University of Health Sciences 
Turkey, İstanbul Training and Research Hospital Ethical Committee (2444/12.06.2020).

\section{Statistical Analysis}

Statistical analysis was performed using SPSS 22.0 for Windows program. Descriptive analysis (number, percentage, mean \pm standard deviation) was used for statistical analysis.

\section{Results}

The number of patients that were called was 101, 86 patients answered and 15 patients did not respond ( 3 calls were made within a 3 day-period and when there was still no answer at all times, the patient was accepted nonresponding). General characteristics of the patients are summarized in Table 1.

When their last registered weight in kg was compared with the present weight declared by the patient, $40.7 \%$ had weight gain ( $n=35), 50 \%$ had weight loss $(n=43)$ and $9.3 \%$ $(n=8)$ patients had same weight (Table 2).

\begin{tabular}{lll}
\multicolumn{3}{l}{ Table 1. General characteristics of the patients } \\
Gender & Female & Male \\
\hline Number of patients (no) & 83 & 3 \\
Age (years) (mean \pm SD) & $50.92 \pm 9.4$ & $59.5 \pm 5.1$ \\
BMI (kg/m ${ }^{2}$ ) & $35.05 \pm 5.2$ & $33.6 \pm 0.37$ \\
WC (cm) & $115.7 \pm 10.01$ & $133 \pm 9.84$ \\
DM rate (number/\%) & $32 / 38.5$ & $2 / 66.6$ \\
HT rate (number/\%) & $39 / 49.9$ & $2 / 66.6$ \\
CRD rate (number/\%) & $4 / 4.8$ & 0 \\
CAD rate (number/\%) & $4 / 4.8$ & $1 / 33.3$ \\
HL rate (number/\%) & $36 / 43.37$ & $1 / 33.3$ \\
Hypothyroidism (number/\%) & $16 / 19.3$ & 0 \\
Malignancy (number/\%) & $3 / 3.6$ & 0 \\
\hline
\end{tabular}

SD: Standard deviation, BMI: Body mass index, DM: Diabetes mellitus, HT: Hypertension, CRD: Chronic renal disease, CAD: Coronary artery disease, HL: Hyperlipidemia
When they were asked about their food consumption, $27.9 \%(n=24)$ of patients were following the recommended diet, $29 \%(\mathrm{n}=29)$ were not following any recommendations about their diet and $33 \%(\mathrm{n}=33)$ were partially following their dietary recommendations. The most common mistake was snacking during the day and at night (Table 2).

When they were asked about their physical activity level, $30.2 \%(n=26)$ of patients were doing home exercises regularly, $50 \%(n=43)$ were not exercising at all and $19.8 \%$ $(\mathrm{n}=17)$ were partially doing home exercises. The most common home exercise was home-walking programmes (Table 2).

When they were asked about how they felt, $53.5 \%(n=46)$ of patients declared to be generally good, $24.4 \%(n=21)$ were generally bad and $22.1(\mathrm{n}=19)$ were partially good. The most common complaints were sleep disturbances and anxiety (Table 2).

All patients declared that they were glad to be called for follow-up and it motivated them. And, it was striking that one patient asked whether she was going to be called again, declaring if so, she was going to pay more attention to her lifestyle recommendations.

\section{Discussion}

COVID-19 pandemic affected great diversity of people from all around the world. Preliminary reports from China led us about general precautions that should be taken to prevent the spread of the disease, diagnosis and treatment methods and highlighted the populations who were at higher risk (7).

Along with several other diseases/conditions, patients with obesity were declared to be at high risk for COVID-19 infection. Diminished immune system and increased inflammatory state were blamed for the susceptibility to

Table 2. Classification of patients' lifestyle changes during pandemic period

\begin{tabular}{llll} 
Weight status & Weight gain & Weight loss & Same weight \\
\hline No/\% of patients & $35 / 40.7$ & $43 / 50$ & $8 / 9.3$ \\
Weight change & $2.85 \pm 2.59$ & $2.41 \pm 1.76$ & 0 \\
[mean \pm SD $(\mathrm{kg})]$ & & & \\
Diet status & Following recommended diet & Not following recommended diet & Partially following recommended diet \\
No/\% of patients & $24 / 27.9$ & $29 / 33.7$ & $33 / 38.4$ \\
Exercise status & Doing recommended home exercises & Not exercising at all & Partially doing recommended home exercises \\
No/\% of patients & $26 / 30.2$ & $43 / 50$ & $17 / 19.8$ \\
Their mood & Generally good & Generally bad & Partially good \\
No/\% of patients & $46 / 53.5$ & $21 / 24.4$ & $19 / 22.1$ \\
\hline
\end{tabular}

SD: Standard deviation 
COVID-19 in obesity and also, for the consequences of the disease (8).

Obesity (48.3\%) was one of the most common underlying diseases in COVID-19 infection along with hypertension (49.7\%), chronic lung disease (34.6\%), diabetes mellitus (28.3\%) and cardiovascular disease (27.8\%) according to centers for diseases control and prevention report. People with obesity had more serious illness, needed more hospital admission and ventilation support. Also, it was pointed out that healthcare could be tricky for people with severe obesity as adequate equipment was not available in every hospital for these individuals (9).

Thus, home isolation was advised to all individuals living with obesity. Living indoors protected people from coronavirus, but at the cost of weight gain as well as increased anxiety, depression, social isolation, decreased sunlight exposure and possible behavioral addiction disorders (10). Snacking, binge eating, eating more meals than ever, having more junk food than ever, decreased physical activity levels and increased sitting time were reported (11).

In our study, $60 \%$ of the patients did not gain weight although one third of the patients did not follow their diet and half of the patients did not exercise at all. It was striking that some patients with obesity actually did lose weight. This was attributed to different reasons: The media declared obesity as one of the reasons of morbidity and mortality in COVID-19 and this might have triggered people with obesity to try harder to lose weight, stay healthy and be able to avoid increased mortality risk related to obesity. Also, some people might have had uncontrolled diabetes or even sarcopenia during pandemic period. Similar results were obtained in a study in Italy, too. In this study by Di Renzo et al. (5), although nearly half of the patients declared they had gained weight, some did quit smoking, some tried to have organic products in their diet and adhered to Mediterranean diet and some increased physical activity, especially resistance training to stay healthy.

Risk of COVID-19 infection, self-quarantine and economical burdens of the situation led to mental distress to nearly everyone who was affected by the pandemic. Depression, perceived discrimination, post-traumatic stress disorder, even suicidal ideation were reported. Mental health of even health-workers was of a concern. It was accepted normal to have anxiety to some extent, but still social isolation was hazardous to people who were already prone to depression (12-14).
In our study, although one fourth of the patients had serious anxiety, majority of the patients could find a way to cope with the psychological consequences of the pandemic. This could be attributed to close family relations and active support among family members in our society as a part of our traditional life.

Home-based exercise, dance, active video-games, any chance to increase physical activity were recommended to cope with anxiety, to improve body composition, postural balance and also cognitive functions in older ages (15). Exercise helped maintaining both physical and mental well-being (16). Making right information sources available, providing effective communication and general and medical needed supplies, making self-isolation a people's choice for health maintenance, and reducing the boredom could help people to get over the distress related to pandemic (17). A study suggested that a telephone support line provided by psychiatric nurses could help to provide a social network (18).

Telemedicine is recommended for mildly ill patients and patients with ongoing chronic diseases. This would both provide the supportive care needed and minimize the exposure to other ill patients (19).

While using telemedicine for patients, standard local regulations must be followed. The audio/video visit should be planned. The time spent, method of telehealth and all visit notes should be documented. Usual visit questions should be asked and answers should be noted. Patients' chief complaint, review of systems, history of complaints, history of patient should be obtained. And in the end, it must be decided whether the patient himself/herself should be seen in person. Otherwise, recommendations must be given and next appointment should be arranged if necessary (19).

In our study, patients were informed via telephone messages informing them they were gonna be called by their doctor in obesity center for follow-up. As there are no specific regulations about tele-medicine, only hospital approval was taken in advance. When the doctor made the call, after getting verbal consent from the patients, they were asked about their present condition regarding obesity and coping with pandemic. All answers, time of calls and recommendations made were recorded. As all patients were seen and examined by the same doctor before and their detailed files were available, the phonecall visit was convenient. However, the doctors should be careful while using telemedicine for a patient they have 
never seen before as medical and legal issues may occur. Although in a study in 2019, the authors found no reported cases of medical malpractice in direct-to-consumer telemedicine, malpractice risk is still present (20). Thus, ethical, legal and financial aspects should be analyzed in detail and be decided whether it is worth practicing telemedicine $(21,22)$. But at extraordinary times like COVID-19 pandemic, it is a convenient tool that can be used without hesitation for patients with chronic diseases like obesity (23).

\section{Conclusion}

Telemedicine is an easy, safe and effective follow-up method for chronic diseases like obesity at extraordinary times like the pandemic period we are going through. Its application can be broader after medical and legal regulations become clear to make both the patients and the healthcare professionals who use this method to be safe in all aspects.

\section{Ethics}

Ethics Committee Approval: Ethical approval was obtained from University of Health Sciences Turkey, İstanbul Training and Research Hospital Ethical Committee (2444/12.06.2020).

Informed Consent: Verbal consent was obtained from all patients after all procedures had been fully explained.

Peer-review: Externally peer-reviewed.

\section{Authorship Contributions}

Concept: F.A., Design: F.A., Data Collection or Processing: F.A., H.U.A., M.E.P., Analysis or Interpretation: F.A., H.U.A., M.E.P., Literature Search: F.A., H.U.A., M.E.P., Writing: F.A.

Conflict of Interest: No conflict of interest was declared by the authors.

Financial Disclosure: The authors declared that this study has received no financial support.

\section{References}

1. Darkins AW, Cary MA. Telemedicine and Telehealth: Principles, Policies, Performances and Pitfalls. New York: Springer Publishing Co, 2000.

2. COVID-19 (Yeni Koronavirüs Hastalığı) Nedir? Available at: https:// covid19.saglik.gov.tr/TR-66300/covid-19-nedir-.html

3. COVID-19. Republic of Health, General Directorate of Public Health. Available at: https://hsgm.saglik.gov.tr/en/

4. Zachary Z, Brianna F, Brianna L, Garrett P, Jade W, Alyssa D, et al. Self-quarantine and weight gain related risk factors during the COVID-19 pandemic. Obes Res Clin Pract 2020;14(3):210-216.
5. Di Renzo L, Gualtieri P, Pivari F, Soldati L, Attinà A, Cinelli G, et al . Eating habits and lifestyle changes during COVID-19 lockdown: an Italian survey. J Transl Med 2020;18(1):229.

6. Ruiz-Roso MB, de Carvalho Padilha P, Mantilla-Escalante DC, Ulloa N, Brun P, Acevedo-Correa D, et al. Covid-19 Confinement and Changes of Adolescent's Dietary Trends in Italy, Spain, Chile, Colombia and Brazil. Nutrients 2020;12(6):1807.

7. Sun P, Lu X, Xu C, Sun W, Pan B. Understanding of COVID-19 based on current evidence. J Med Virol 2020;92(6):548-551.

8. Carter SJ, Baranauskas MN, Fly AD. Considerations for Obesity, Vitamin D, and Physical Activity Amid the COVID-19 Pandemic. Obesity (Silver Spring) 2020;28(7):1176-1177.

9. Finer N, Garnett SP, Bruun JM. COVID-19 and obesity. Clin Obes 2020;10(3):e12365.

10. Lippi G, Henry BM, Bovo C, Sanchis-Gomar F. Health risks and potential remedies during prolonged lockdowns for coronavirus disease 2019 (COVID-19). Diagnosis (Berl) 2020;7(2):85-90.

11. Ammar A, Brach M, Trabelsi K, Chtourou H, Boukhris O, Masmoudi L, et al. Effects of COVID-19 Home Confinement on Eating Behaviour and Physical Activity: Results of the ECLB-COVID19 International Online Survey. Nutrients 2020;12(6):1583.

12. Ng LL. Psychological states of COVID-19 quarantine. J Prim Health Care 2020;12(2):115-117.

13. Tang W, Hu T, Hu B, Jin C, Wang G, Xie C, et al. Prevalence and correlates of PTSD and depressive symptoms one month after the outbreak of the COVID-19 epidemic in a sample of homequarantined Chinese university students. J Affect Disord 2020;274:1-7.

14. Xin M, Luo S, She R, Yu Y, Li L, Wang S, et al. Negative cognitive and psychological correlates of mandatory quarantine during the initial COVID-19 outbreak in China. Am Psychol 2020;75(5):607617.

15. Viana RB, de Lira CAB. Exergames as Coping Strategies for Anxiety Disorders During the COVID-19 Quarantine Period. Games Health J 2020;9(3):147-149.

16. Matias T, Dominski FH, Marks DF. Human needs in COVID-19 isolation. J Health Psychol 2020;25(7):871-882.

17. Brooks SK, Webster RK, Smith LE, Woodland L, WesselyS, Greenberg $\mathrm{N}$, et al. The psychological impact of quarantine and how to reduce it: rapid review of the evidence. Lancet 2020;395(10227):912-920.

18. Maunder R, Hunter J, Vincent L, Bennett J, Peladeau N, Leszcz $\mathrm{M}$, et al. The immediate psychological and occupational impact of the 2003 SARS outbreak in a teaching hospital. CMAJ 2003;168(10):1245-1251.

19. Portnoy J, Waller M, Elliott T. Telemedicine in the Era of COVID-19. J Allergy Clin Immunol Pract 2020;8(5):1489-1491.

20. Fogel AL, Kvedar JC. Reported Cases of Medical Malpractice in Direct-to-Consumer Telemedicine. JAMA 2019;321(13):1309-1310.

21. Daragó L, Jung Z, Ispán F, Bendes R, Dinya E. [Benefits and disadvantages of telemedicine]. Orv Hetil 2013;154(30):1167-1171.

22. Stanberry B. Legal and ethical aspects of telemedicine. J Telemed Telecare 2006;12(4):166-175.

23. Tarraga Marcos ML, Panisello Royo JM, Carbayo-Herencia JA, Rosich Domenech N, Alins Presas J, Castell Panisello E, et al. Application of telemedicine in obesity management. Eur Res Telemed 2017;6(1):3-12. 